\title{
Is talon tibial intramedullary nailing clinically superior compared to conventional locked nailing?
}

\author{
Talon tibial intramedüller çivileme konvansiyonel kilitli çivilemeye göre \\ klinik olarak üstün müdür?
}

\author{
Yalkın Çamurcu, MD., ${ }^{1}$ Hakan Sofu, MD., ${ }^{1}$ Ahmet Issın, MD., ${ }^{1}$ Nizamettin Koçkara, MD., ${ }^{1}$ \\ Erdinç Genç, MD., ${ }^{2}$ Mehmet Çetinkaya, MD. ${ }^{2}$ \\ 1Department of Orthopedics and Traumatology, Medical Faculty of Erzincan University, Erzincan, Turkey \\ ${ }^{2}$ Department of Orthopedics and Traumatology, Mengucek Gazi Training and Research Hospital, Erzincan, Turkey
}

\begin{abstract}
Objectives: This study aims to compare the results of talon tibial intramedullary (IM) nailing with the results of conventional distal locked tibial IM nailing.

Patients and methods: The study included 60 patients (37 males, 23 females; mean age 42.2 years; range 18 to 92 years) who underwent tibial IM nailing with the diagnosis of unilateral, closed or open (Gustilo-Anderson type 1) tibial diaphyseal fracture (Orthopaedic Trauma Association 42) between January 2013 and January 2016. Patients were separated into two groups as talon tibial IM nailing group (group 1, n=30) and distal locked tibial IM nailing group (group 2, $n=30$ ). All patients' operative and total radiation exposure times were recorded. At last control, American Orthopaedic Foot and Ankle Society and Tegner Lysholm scores were evaluated for clinical outcomes. All complications were recorded.
\end{abstract}

Results: Mean operative time was 43.8 minutes in group 1 and 50.2 minutes in group 2. Mean radiation exposure time in group 1 was 5.4 minutes, which was three times shorter than the time of group 2, which was 17.5 minutes. Mean time until union was 16.9 weeks in group 1 and 12.2 weeks in group 2 . Statistically significant differences were present between two groups in operative, radiation exposure time and time until union ( $\mathrm{p}=0.019, \mathrm{p}=0.001, \mathrm{p}=0.001$, respectively). When American Orthopaedic Foot and Ankle Society and Tegner Lysholm scores were compared, there were no statistically significant differences ( $\mathrm{p}=0.951$ and $\mathrm{p}=0.896)$.

Conclusion: Talon tibial IM nailing is an easier and safer alternative to conventional distal locked tibial IM nailing with shorter operative and radiation exposure times. However, it should be kept in mind that the time until radiographic union may be longer compared to conventional tibial IM nailing.

Keywords: Distal locking; fracture healing; intramedullary nailing; talon; radiation dosage; tibial fracture.
ÖZ

Amaç: Bu çalışmada talon tibial intramedüller (IM) çivilemenin sonuçları ile konvansiyonel distal kilitli tibial İM çivilemenin sonuçları karşılaştırıldı.

Hastalar ve yöntemler: Çalışmaya Ocak 2013 - Ocak 2016 tarihleri arasında tek taraflı, kapalı veya açık (Gustilo-Anderson tip 1) tibia diyafiz kırığı (Ortopedik Travma Birliği 42) tanısı ile tibial İM çivileme yapılan 60 hasta $(37$ erkek, 23 kadın; ort. yaş 42.2 yıl; dağılım 18-92 yıl) dahil edildi. Hastalar talon tibial İM çivileme grubu (grup $1, n=30$ ) ve distal kilitli tibial İM çivileme grubu (grup 2, n=30) olmak üzere iki gruba ayrıldı. Tüm hastaların ameliyat ve toplam radyasyona maruz kalma süreleri kaydedildi. Son kontrolde, Amerikan Ortopedik Ayak ve Ayak Bileği Derneği ve Tegner Lysholm skorları klinik sonuçlar açısından değerlendirildi. Tüm komplikasyonlar kaydedildi.

Bulgular: Ortalama ameliyat süresi grup 1'de 43.8 dakika, grup 2'de 50.2 dakika idi. Grup 1'de ortalama radyasyona maruz kalma süresi 5.4 dakika idi ve bu süre 17.5 dakika olan grup 2'nin süresinden üç kat daha kısa idi. Kaynamaya kadar geçen ortalama süre, grup 1'de 16.9 hafta ve grup 2'de 12.2 hafta idi. Ameliyat, radyasyona maruz kalma ve kaynama sürelerinde iki grup arasında istatistiksel olarak anlamlı farklılıklar vardı (sırasıyla $\mathrm{p}=0.009, \mathrm{p}=0.001, \mathrm{p}=0.001)$. Amerikan Ortopedik Ayak ve Ayak Bileği Derneği ve Tegner Lysholm skorları karşılaştırıldığında, istatistiksel olarak anlamlı farklılık yoktu ( $\mathrm{p}=0.951$ ve $\mathrm{p}=0.896)$.

Sonuç: Talon tibial İM çivileme, daha kısa ameliyat ve radyasyona maruz kalma süreleri ile konvansiyonel distal kilitli tibial İM çivilemenin daha kolay ve güvenilir bir alternatifidir. Bununla birlikte, radyografik kaynamaya kadar geçen sürenin konvansiyonel tibial İM çivilemeye kıyasla daha uzun olabileceği akılda tutulmalıdır.

Anahtar sözcükler: Distal kilitleme; kırık iyileșmesi; intramedüller çivileme; talon; radyasyon dozu; tibia kırığı.

- Received: February 22, 2017 Accepted: May 29, 2017

- Correspondence: Yalkın Çamurcu, MD. Erzincan Üniversitesi Tıp Fakültesi Ortopedi ve Travmatoloji Anabilim Dalı, 24100 Erzincan, Turkey, Tel: +90 533 - 4802310 e-mail: yalkin.camurcu@gmail.com 
Intramedullary nailing remains the most favorable choice of treatment for the diaphyseal fractures of the tibia. ${ }^{[1,2]}$ Tibial intramedullary (IM) nails can be grouped as locked or historical unlocked nails. During locked tibial IM nailing procedure, proximal interlocking screws can be placed easily by proximal targeting device; however, there are various methods for the placement of distal interlocking screws, which can increase radiation exposure time and lengthen the entire operative time.

Talon Distal Fix is a new generation tibial IM nail, which eliminates distal locking screws with four deployable distal talons. In a biomechanical study of hip compression screw with deployable talons, Bramlet and Wheeler ${ }^{[3]}$ reported that talon deployment significantly improved the interfragment torsion and compression strength. Furthermore, Zehir et al. ${ }^{[4]}$ reported lower cut-out rates and shorter operative times with talon distal fix/lag screw proximal femoral nail when compared to other proximal femoral nail types.

To our knowledge, no study was conducted on the results of talon tibial IM nailing in the literature. Therefore, in this study, we aimed to compare the results of talon tibial IM nailing with the results of conventional distal locked tibial IM nailing.

\section{PATIENTS AND METHODS}

This retrospective study included 60 patients ( 37 males, 23 females; mean age 42.2 years; range 18 to 92 years) who underwent tibial IM nailing between January 2013 and January 2016 with the diagnosis of unilateral, closed or open (Gustilo-Anderson type 1) tibial diaphyseal fracture at Erzincan University Faculty of Medicine, Mengucek Gazi Education and Training Hospital. Fractures were classified according to Orthopaedic Trauma Association (OTA) classification. Inclusion criteria were patients aged over 18 years with a minimum follow-up of 12 months and an isolated OTA 42 tibial diaphyseal fracture. Patients with distal extraarticular tibial metophyseodiaphyseal fracture (OTA 43A), which were not suitable for talon tibial IM nailing, and lost to follow-up because of leaving the state or unknown reasons were excluded. Patients were grouped according to the type of the tibial IM nail used. There were 30 patients in talon tibial IM nailing (Talon Distal Fix Tibial Nail System, Orthopedic Designs; North America Inc., Florida, USA) group (group 1) and 30 patients in distal locked tibial IM nailing (Trigen Meta-Nail Tibial Nail System; Smith \& Nephew Inc., Memphis, TN, USA) group (group 2). The study protocol was approved by the Erzincan University Faculty of Medicine, Clinical
Researchs Ethics Committee. A written informed consent was obtained from each patient. The study was conducted in accordance with the principles of the Declaration of Helsinki.

For talon tibial IM nailing, the patient was placed supine on the operating table with the knee flexed over the end of the table, and the thigh was supported with padding. A tip threaded guide wire was inserted into the proximal tibia through transpatellar incision. After proximal tibial reaming through guidewire, a pinball threaded guide wire was inserted into the medullary canal. After reaming the medullary canal, an appropriate size tibial IM nail was inserted. For the distal locking of the tibial IM nail, the talon driver was inserted into the IM nail, and it was turned clockwise to deploy the talons. Talons were deployed until reaching the torque limit, or the lengths of the talons were appropriate at fluoroscopy. Proximal locking was performed by two or three locking screws through the proximal guide arm.

For conventional distal locked tibial IM nailing, the steps of the surgical technique were same as talon IM nailing except the distal locking step. After inserting the tibial IM nail, distal locking screws were placed by free-hand technique under fluoroscope control.

All patients had concomitant ipsilateral fibular fracture, and no patient underwent plate fixation of fibular fracture. The operative time was measured from the first incision to the closure of the wounds, and the total radiation exposure time was measured and noted for all patients routinely. Last control anteroposterior and lateral radiographs were measured and deformities were noted (varus-valgus $>5$ degrees, procurvatum/recurvatum $>10$ degrees), if detected. Patients were called for follow-up examinations at postoperative second week, fourth week, and eighth week and then at four-week intervals until union of fracture was achieved. The union of the fracture was assessed by two criteria: 1) the ability of weight bearing without pain, 2) observation of callus formation on at least three out of four cortices on the anteroposterior and lateral radiographs. At last control, clinical outcomes were evaluated by The American Orthopaedic Foot and Ankle Society (AOFAS) foot and ankle scoring system and Tegner Lysholm knee scoring scale. All complications were recorded.

\section{Statistical analysis}

IBM SPSS for Windows version 20.0 software (IBM Corp., Armonk, NY, USA) was used for statistical analysis. Comparison of two independent 
TABLE I

Demographic data and fracture classifications of patients

\begin{tabular}{|c|c|c|c|c|c|c|}
\hline & \multicolumn{3}{|c|}{$\begin{array}{c}\text { Group } 1(\mathrm{n}=30) \\
\text { (Talon tibial IM nail) }\end{array}$} & \multicolumn{3}{|c|}{$\begin{array}{c}\text { Group } 2(\mathrm{n}=30) \\
\text { (Distal locked IM nail) }\end{array}$} \\
\hline & $n$ & Mean \pm SD & Range & $\mathrm{n}$ & Mean $\pm S D$ & Range \\
\hline Age (year) & & $41.3 \pm 17.9$ & $20-92$ & & $43.1 \pm 19.3$ & $18-92$ \\
\hline \multicolumn{7}{|l|}{ Gender } \\
\hline Female & 12 & & & 11 & & \\
\hline Male & 18 & & & 19 & & \\
\hline \multicolumn{7}{|c|}{ Open fracture } \\
\hline Type 1 & 5 & & & 6 & & \\
\hline \multicolumn{7}{|c|}{ Fracture classification (OTA) } \\
\hline $42 \mathrm{~A}$ & 17 & & & 13 & & \\
\hline $42 \mathrm{~B}$ & 12 & & & 17 & & \\
\hline $42 \mathrm{C}$ & 1 & & & 0 & & \\
\hline
\end{tabular}

IM: Intramedullary; SD: Standard deviation; OTA: Orthopaedic Trauma Association.

groups was analyzed by Mann-Whitney $U$ test and t-test in accordance with Shapiro-Wilk normality test. $P$ values lower than 0.05 were considered as statistically significant.

\section{RESULTS}

Patients' demographic data and fracture classifications were demonstrated in Table I. Mean follow-up time was $15.9 \pm 3.2$ months (range, 12 to 22 months) in group 1 and $18.1 \pm 7.1$ months (range, 12 to 39 months) in group 2. Mean operative and radiation exposure times were significantly shorter in group $1(\mathrm{p}=0.009$ and $\mathrm{p}=0.000$, respectively) (Table II). Mean time until union was $16.9 \pm 5.5$ weeks (range, 8 to 24 weeks) in group 1 and $12.2 \pm 4.3$ weeks (range, 8 to 28 weeks) in group 2. Mean time until union in group 1 was four weeks longer than group 2, with a statistically significant difference $(\mathrm{p}=0.001)$ (Figures 1 and 2$)$.
There were five patients in group 1 and six patients in group 2 with the diagnosis of GustiloAnderson type 1 open tibial diaphyseal fracture. For type 1 open fractures, the mean time until union was 16.3 weeks (range, 12 to 24 weeks) in group 1 and 12.1 weeks (range, 12 to 28 weeks) in group 2 . When we reviewed the time until union according to OTA classification; in OTA 42A fractures, the mean time until union was 16.7 weeks in group 1 and 12 weeks in group 2. In OTA 42B fractures, the mean time until union was 16.4 weeks in group 1 and 11.7 weeks in group 2.

The mean AOFAS score was $82.6 \pm 10.2$ in group 1 and $82.8 \pm 10.6$ in group 2, while the mean Tegner Lysholm score was $79.7 \pm 8.6$ in group 1 and $79.4 \pm 9$ in group 2 . There was no statistically significant difference between groups when clinical scores were compared ( $\mathrm{p}=0.951$ and $\mathrm{p}=0.896)$ (Table II).

TABLE II

Follow-up, operative data, time until union and clinical scores of patients

\begin{tabular}{lccc}
\hline & $\begin{array}{c}\text { Group 1 }(\mathrm{n}=30) \\
\text { (Talon tibial IM nail) }\end{array}$ & & $\begin{array}{c}\text { Group 2 }(\mathrm{n}=30) \\
\text { (Distal locked IM nail) }\end{array}$ \\
\cline { 2 - 3 } & $\begin{array}{lcc}\text { Mean } \pm S D \\
\text { Follow-up (month) }\end{array}$ & $15.9 \pm 3.2$ & $18.1 \pm 7.1$ \\
Operative time (minute) & $43.8 \pm 7.8$ & $50.2 \pm 12.1$ \\
Radiation exposure time (minute) & $5.4 \pm 0.93$ & $17.5 \pm 4.8$ \\
Time until union (week) & $16.9 \pm 5.5$ & $12.2 \pm 4.3$ \\
AOFAS score (points) & $82.6 \pm 10.2$ & $82.8 \pm 10.6$ \\
Tegner Lysholm score (points) & $79.7 \pm 8.6$ & $79.4 \pm 9$ \\
\hline
\end{tabular}

SD: Standard deviation. 

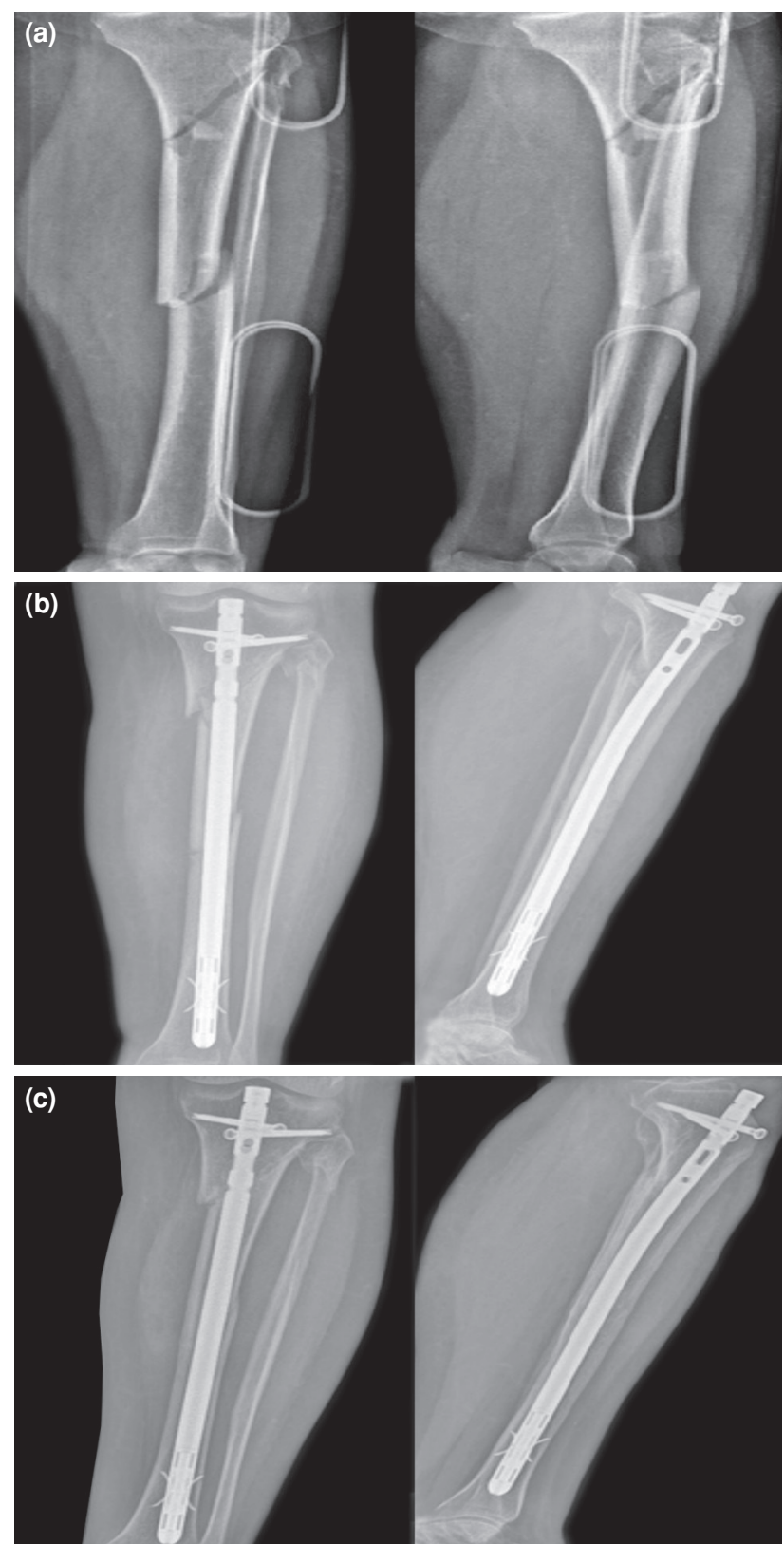

Figure 1. A 51-year-old female patient with a diagnosis of Orthopaedic Trauma Association 42C segmental tibial diaphyseal fracture who underwent talon tibial intramedullary nailing. (a) Preoperative, (b) postoperative second week and (c) $24^{\text {th }}$ week controls (time until union) anteroposterior and lateral radiographs.

One patient in group 1 had non-union until postoperative $12^{\text {th }}$ month and underwent IM nail exchange (larger size talon IM nail) with autologous iliac bone grafting. Union was seen on radiographs at postoperative $12^{\text {th }}$ week after IM nail revision. Four patients in group 1 (one varus, three recurvatum) and four patients in group 2 (one varus, one valgus, two recurvatum) had malunion with no complaints. Two patients in group 1 and one patient in group 2 had superficial infection postoperatively, which recovered completely with two weeks of antibiotherapy. One patient in group 2 had deep venous thrombosis, which was diagnosed at postoperative second week and which recovered totally at sixth month follow-up.

\section{DISCUSSION}

Tibial diaphyseal fractures are the most common long bone fractures in which IM nailing is the most favored treatment method in current orthopaedic practice. ${ }^{[5]}$ Distal locking conventional nails rely on interlocking screws for axial and rotational stability. Despite the advantage of axial and rotational stability, locking tibial IM nails have some surgical disadvantages like neurovascular injuries, soft tissue damage and difficulty of inserting distal locking screw, which increase operative and radiation exposure time. ${ }^{[6]}$ According to the results of this study, talon tibial IM nailing had shorter operative and radiation exposure times; however, time until union was longer when compared to conventional distal locking tibial IM nailing. Clinical and radiological results were successful in both techniques.

To the best of our knowledge, no study is present in the literature about the results of talon tibial IM nailing for the surgical treatment of tibial diaphyseal fractures. As an example to unlocked tibial IM nailing, expandable tibial IM nailing is a method of fixation with a historical background which provides stability in all planes without need of interlocking screws. ${ }^{[7]}$ In a review, results of an expandable tibial IM nail were evaluated through 10 studies and authors reported that the mean time until union was 12.3 weeks. ${ }^{[8]}$ Ghafil et al. ${ }^{[9]}$ reported the results of expandable tibial IM nailing in 52 patients with OTA $42 \mathrm{~A}$ and $42 \mathrm{~B}$ fractures; in this study, the mean time until union was 15.8 weeks. On the other hand, Lee et al. ${ }^{[10]}$ compared unlocked tibial IM nailing with locked tibial nailing and found no significant difference in healing time and malunion rate. In their study, the mean time until union was 16.2 weeks in unlocked IM nailing group. ${ }^{[10]}$ In our study, the mean time until union was four weeks longer in talon tibial IM nailing group when compared to conventional distal locked tibial IM nailing group. However, time until union was slightly similar to the results reported in the literature.

Kneifel and Buckley ${ }^{[1]]}$ compared the numbers of distal locking screws in tibial IM nailing and reported that one distal screw failed more often than two distal screws; however, they found no significant difference between times until union. In a biomechanical study comparing two distal locking screws, three distal 

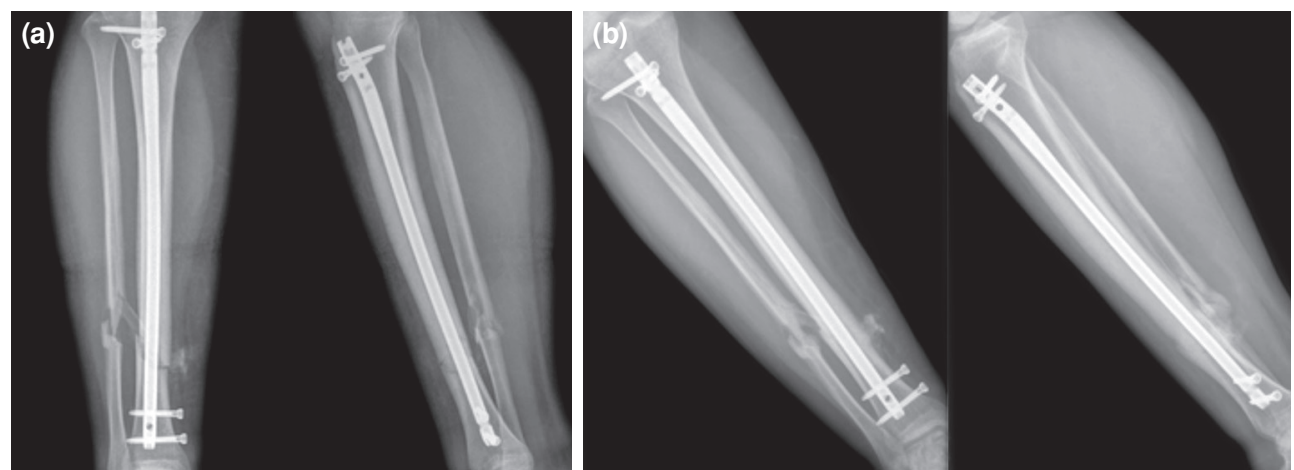

Figure 2. (a) Postoperative second week and (b) $12^{\text {th }}$ week controls (time until union) anteroposterior and lateral radiographs of a 22-year-old male patient with a diagnosis of Orthopaedic Trauma Association 42B tibial diaphyseal fracture who underwent distal locked tibial intramedullary nailing.

locking screws, and two distal locking screws with single blocking screw, authors observed that three distal locking screws were superior to other groups with improved axial construct stiffness. ${ }^{[12]}$ However, they found no significant difference between groups in rotational stability. ${ }^{[12]}$ In this study, we experienced that conventional tibial IM nail with two distal locking screws provided a more rigid fixation when compared to talon tibial IM nail with four talons since we observed that bridging callus of talon tibial IM nails were more visible in radiographs than distal locked tibial IM nails. Besides, the mean time until union in talon tibial IM nailing group was four weeks longer than distal locked tibial IM nailing group, which also indicated the reduced stability of fixation.

The use of fluoroscopy in orthopaedic trauma surgery increased in recent years with minimalinvasive techniques. Increased radiation exposure and operative time due to distal locking of tibial IM nails led the investigators to search various techniques of distal locking screw placement to reduce operative and radiation exposure times. ${ }^{[13]}$ In this study, we evaluated the radiation exposure dose by measuring the radiation exposure time, and according to our results, the mean exposure time of talon tibial IM nailing group was three times shorter than distal locked tibial IM nailing group. The main advantage of the talon tibial IM nailing was decreased radiation exposure time of the orthopaedic surgeon and patient due to the distal locking with four deployable talons without need of any distal locking technique. Another advantage of talon tibial IM nailing was decreased operative time, showing the convenience of the technique.

When we reviewed the clinical outcomes and complications, there was no difference between two groups in this study. Four patients in each group had malunion with no clinical complaints. Because of lower stability of talon tibial IM nails when compared to distal locked tibial IM nails; we were expecting increased malunion rates. However, there was no difference in malunion rates between groups. Shortening of the fracture and talon failure, which showed insufficient axial stability, were not observed during follow-up. Deployable talons of the talon tibial IM nail must stab into the cortex of the tibia, and it is important to place the IM nail in appropriate position. In distal diaphyseal extraarticular fractures of the tibia, talon tibial IM nail is not an appropriate choice of implant because talons in the metaphyseal region of the tibia may cause instability and malunion.

The main limitations of this study were its retrospective design and small patient population. However, to our knowledge, the present study was the first to report the preliminary results of talon tibial IM nailing in comparison to conventional distal locked tibial IM nailing. Besides, the minimum follow-up time of 12 months was adequate to evaluate the union status. Further prospective randomized studies in large patient populations are required to evaluate the clinical and radiological results of this newly generated tibial IM nailing.

In conclusion, talon tibial IM nailing is an easier and safer alternative to distal locked conventional tibial IM nailing with reduced operative and radiation exposure times in OTA 42 tibial diaphyseal fractures. However, it should be kept in mind that the time until radiographic union might be longer than time with conventional tibial IM nails.

\section{Declaration of conflicting interests}

The authors declared no conflicts of interest with respect to the authorship and/or publication of this article. 


\section{Funding}

The authors received no financial support for the research and/or authorship of this article.

\section{REFERENCES}

1. Baki ME, Aldemir C, Duygun F, Doğan A, Kerimoğlu G. Comparison of non-compression and compression interlocking intramedullary nailing in rabbit femoral shaft osteotomy model. Eklem Hastalik Cerrahisi 2017;28:7-12.

2. Karakaşli A, Satoğlu İS, Havitçioğlu H. A new intramedullary sustained dynamic compression nail for the treatment of long bone fractures: a biomechanical study. Eklem Hastalik Cerrahisi 2015;26:64-71.

3. Bramlet DG, Wheeler D. Biomechanical evaluation of a new type of hip compression screw with retractable talons. J Orthop Trauma 2003;17:618-24.

4. Zehir S, Şahin E, Zehir R. Comparison of clinical outcomes with three different intramedullary nailing devices in the treatment of unstable trochanteric fractures. Ulus Travma Acil Cerrahi Derg 2015;21:469-76.

5. Obremskey WT, Cutrera N, Kidd CM. A prospective multicenter study of intramedullary nailing vs casting of stable tibial shaft fractures. J Orthop Traumatol 2017;18:69-76.

6. Williams J, Gibbons M, Trundle H, Murray D, Worlock P.
Complications of nailing in closed tibial fractures. J Orthop Trauma 1995;9:476-81.

7. Fortis AP, Dimas A, Lamprakis AA. Expandable nailing system for tibial shaft fractures. Injury 2008;39:940-6.

8. Beazley J, Mauffrey C, Seligson D. Treatment of acute tibial shaft fractures with an expandable nailing system: a systematic review of the literature. Injury 2011;42:11-6.

9. Ghafil D, Ackerman P, Baillon R, Verdonk R, Delince P. Expandable intramedullary nails for fixation of tibial shaft fractures. Acta Orthop Belg 2012;78:779-85.

10. Lee YS, Lo TY, Huang HL. Intramedullary fixation of tibial shaft fractures: a comparison of the unlocked and interlocked nail. Int Orthop 2008;32:69-74.

11. Kneifel T, Buckley R. A comparison of one versus two distal locking screws in tibial fractures treated with unreamed tibial nails: a prospective randomized clinical trial. Injury 1996;27:271-3.

12. Chan DS, Nayak AN, Blaisdell G, James CR, Denard A, Miles J, et al. Effect of distal interlocking screw number and position after intramedullary nailing of distal tibial fractures: a biomechanical study simulating immediate weight-bearing. J Orthop Trauma 2015;29:98-104.

13. Aldemir C, Doğan A, İnci F, Sertkaya Ö, Duygun F. Distal locking techniques without fluoroscopy in intramedullar nailing. [Article in Turkish] Eklem Hastalik Cerrahisi 2014;25:64-9. 